\title{
Raf-induced MMP9 disrupts tissue architecture of human breast cells in three-dimensional culture and is necessary for tumor growth in vivo
}

\author{
Alain Beliveau, ${ }^{1,5,7}$ Joni D. Mott, ${ }^{1}$ Alvin Lo, ${ }^{1}$ Emily I. Chen, ${ }^{2}$ Antonius A. Koller, ${ }^{3}$ Paul Yaswen, ${ }^{1}$ \\ John Muschler, ${ }^{4}$ and Mina J. Bissell ${ }^{1,6}$ \\ ${ }^{1}$ Life Sciences Division, Lawrence Berkeley National Laboratory, Berkeley, California 94720, USA; ${ }^{2}$ Department of \\ Pharmacological Sciences, Stony Brook University, Stony Brook, New York 11794, USA; ${ }^{3}$ Proteomics Center and Department \\ of Pathology, School of Medicine, Stony Brook University, Stony Brook, New York 11794, USA; ${ }^{4}$ California Pacific Medical \\ Center Research Institute, San Francisco, California 94107, USA
}

Organization into polarized three-dimensional structures defines whether epithelial cells are normal or malignant. In a model of morphogenesis, we show that inhibiting key signaling pathways in human breast cancer cells leads to "phenotypic reversion" of the malignant cells. Using architecture as an endpoint, we report that, in all cases, signaling through Raf/MEK/ERK disrupted tissue polarity via matrix metalloproteinase9 (MMP9) activity.

Induction of Raf or activation of an engineered, functionally inducible MMP9 in nonmalignant cells led to loss of tissue polarity, and reinitiated proliferation. Conversely, inhibition of Raf or MMP9 with small molecule inhibitors or shRNAs restored the ability of cancer cells to form polarized quiescent structures. Silencing MMP9 expression also reduced tumor growth dramatically in a murine xenograft model. LC-MS/MS analysis comparing conditioned medium from nonmalignant cells with or without active MMP9 revealed laminin 111 (LM1) as an important target of MMP9. LM1 has been implicated in acinar morphogenesis; thus, its degradation by MMP9 provides a mechanism for loss of tissue polarity and reinitiation of growth associated with MMP9 activity. These findings underscore the importance of the dynamic reciprocity between the extracellular matrix integrity, tissue polarity, and Raf/MEK/ERK and MMP9 activities, providing an axis for either tissue homeostasis or malignant progression.

[Keywords: Breast cancer cells; MAPK; matrix metalloproteinase9 (MMP9); tissue architecture; three-dimensional (3D) culture models]

Supplemental material is available for this article.

Received September 7, 2010; revised version accepted November 1, 2010.

Coordinated integration of morphogenic and proliferation cues is required for all aspects of development and is essential for maintenance of tissue specificity and organ architecture. During tumorigenesis, this regulation is lost, allowing malignant cells to proliferate and invade the surrounding stroma. Loss of tissue organization is among the earliest hallmarks of premalignant breast disease, and breast tumors are graded essentially on the basis of nuclear, cell, and tissue histology, those with the most disrupted epithelial organization having the poorest prognosis (Elston and Ellis 2002).

\footnotetext{
${ }^{5}$ Present address: Research Centre, Centre Hospitalier de l'Université de Montréal (CHUM), 1560 Sherbrooke East, Montreal, Quebec H2L 4M1, Canada.

Corresponding authors.

${ }^{6}$ E-MAIL MJBissell@lbl.gov; FAX (510) 486-4365.

${ }^{7}$ E-MAIL alain.beliveau.chum@ssss.gouv.qc.ca; FAX (514) 412-7624.

Article is online at http://www.genesdev.org/cgi/doi/10.1101/gad.1990410.
}

The key interplay between tissue architecture and proliferation is not trivial to model ex vivo. When nonmalignant cells from epithelial tissues such as liver and the mammary gland are cultured as two-dimensional (2D) monolayers, they lose tissue-specific functions rapidly (DM Bissell 1981; MJ Bissell 1981; Walpita and Hay 2002). Culturing mouse mammary epithelial cells or human mammary epithelial cells (HMECs) on a laminin (LM)-rich extracellular matrix (lrECM) restores a number of cues received by these cells in vivo, and recapitulates aspects of gene expression, tissue architecture, and function (Barcellos-Hoff et al. 1989; Streuli and Bissell 1990; Streuli et al. 1991; Muschler et al. 1999; Gudjonsson et al. 2002; Alcaraz et al. 2008; Xu et al. 2009). Nonmalignant HMECs and mouse mammary epithelial cells cultured in or on three-dimensional (3D) lrECM undergo a process of acinar morphogenesis only when LM1 is present; after an initial proliferative phase, the cells arrest growth and form a polarized colony reminiscent of acini in vivo. Breast 
tumor cells lose the ability to respond to these signals and form continuously proliferating, disorganized colonies (Petersen et al. 1992). Using this versatile model, we showed that, by modulating a number of key signaling pathways, coordination between proliferation and tissue polarity could be re-established in several breast cancer cell lines despite the fact that the malignant genome remains intact (Weaver et al. 1997, 2002; Wang et al. 2002; Rizki et al. 2008). We refer to this restoration of acinar morphogenesis by breast tumor cells in $3 \mathrm{D}$ as "phenotypic reversion" (Weaver et al. 1997). Whereas mechanisms underlying cell proliferation in breast cancer have been studied in detail in 2D cultures, critical mediators influencing loss of tissue organization and disrupted growth in early tumor progression remain poorly defined. Here, we sought to find common regulatory molecule(s) that could integrate the function of different agents that revert the malignant phenotype in 3D.

Matrix metalloproteinases (MMPs) are frequently upregulated in the tumor microenvironment (Deryugina and Quigley 2006). MMPs influence many aspects of tissue function by cleaving a diverse range of ECM, cell adhesion, and cell surface receptors, and regulate the bioavailability of many grow th factors and chemokines (Egeblad and Werb 2002; Page-McCaw et al. 2007). We postulated that MMP activity is a key determinant of loss of tissue organization in malignant transformation (Bissell et al. 2005), and sought to determine whether expression of such activity could be a common denominator in phenotypic reversion. Using nonmalignant (S1) and malignant (T4-2) human breast epithelial cells from the same individual (Briand et al. 1996; Weaver et al. 1997), we found that MMP9 was regulated by Raf/MEK/ERK signaling in 3D cultures. Suppression of either MEK or MMP9 using shRNAs allowed T4-2 cells to form quiescent structures with correct basal polarity. Moreover, silencing MMP9 significantly impaired tumor formation in mice. Conversely, inducible activation of Raf or MMP9 in growth-arrested polarized acini disrupted tissue architecture and reinitiated proliferation. LCMS/MS analysis comparing conditioned medium (CM) from nonmalignant cells with or without active MMP9 revealed that the all three LM1 subunits were targeted by MMP9 activity. Because a role for LM1 in the onset of acinar morphogenesis has been demonstrated, current results imply that MMP9-induced LM1 cleavage is most likely responsible for initiating the loss of acinar structural integrity. These data identify a novel axis of cell regulation relevant to tumor progression, revealing a critical connection between the known oncogenic signaling pathways, MMPs, and the microenvironment, leading to the loss of homeostasis imposed by tissue architecture and polarity on gene expression and proliferation.

\section{Results}

MMP9 activity is a key determinant of the loss of tissue polarity in $3 D$ cultures

The S1 and T4-2 cells of the HMT3522 breast tumor progression series were obtained from reduction mam- moplasty without the use of exogenous oncogenes or serum (Briand et al. 1996). Cultured in 3D lrECM, this series provides a robust model for studying acquisition, maintenance, disruption, and reacquisition of tissue polarity. Whereas nontumorigenic S1 cells form growtharrested, polar colonies resembling mammary acini, the tumorigenic counterpart, T4-2 cells, forms disorganized colonies that continue to grow (Petersen et al. 1992). However, the T4-2 tumorigenic phenotype can be reverted by interfering with a number of signaling pathways (Bissell et al. 2005). Here, we evaluated the effect of a broadspectrum MMP inhibitor, GM6001, and a clinically tested MMP inhibitor, Marimastat (Coussens et al. 2002), on T4-2 cell behavior in 3D cultures (Fig. 1A,B). Both inhibitors induced striking morphological reversion of the malignant phenotype in contrast to vehicle-treated cells. The reversion was similar to that obtained with other signaling inhibitors, including inhibitory antibodies and small molecule inhibitors targeting $\beta 1$-integrin and EGFR (Weaver et al. 1997; Wang et al. 1998), PI3K (Liu et al. 2004), TACE (Kenny and Bissell 2007), Rap-1 (Itoh et al. 2007), and HoxD10 (Chen et al. 2009), among others (Bissell et al. 2005). Zymography of CM revealed that S1 cells produced a small amount of MMP9 in 2D cultures, but no detectable MMP9 following acinar morphogenesis in 3D lrECM cultures. In contrast, the level of MMP9 was significant in T4-2 cells regardless of culture conditions (Fig. 1C), and T4-2 cells did not express MMP2, precluding a role for this proteinase in its malignant behavior.

We asked whether MMP9 activity could be a common denominator of reversion. T4-2 cells were treated in 3D lrECM with AG1478 (EGFR inhibitor) (Wang et al. 1998; Kenny and Bissell 2007), Ly294002 (PI3K inhibitor) (Liu et al. 2004), and GM6001. In all cases, reversion of the malignant phenotype was accompanied by a dramatic decrease in MMP9 (Fig. 1D), despite the fact that each of these agents inhibits unique targets (A Beliveau and MJ Bissell, unpubl.). Additionally, the observation that reexpression of HoxD10 reverted T4-2 cells and was accompanied by down-modulation of MMP9 expression (Chen et al. 2009) suggested that suppression of MMP9 might be essential in the formation of stable polarized colonies.

To test this directly, T4-2 cells were transfected with shRNA to specifically down-modulate MMP9 expression (Fig. 1E). Scrambled shRNA is not processed by the RNAinduced silencing complex (RISC) and may not be an adequate control (White and Allshire 2004); thus, T4-2 cells were stably transduced with a GFP-expressing retrovirus to create the T4-2 ${ }^{\text {GFP }}$ control cell line. Downmodulation of GFP expression with shRNA had no apparent effect on colony morphology (Fig. 1F), cell proliferation, or survival (data not shown), and served as an appropriate control for subsequent experiments.

T4-2 ${ }^{\text {GFP }}$ cells transduced with either shGFP or shMMP9 were grown in 3D lrECM and were evaluated by immunofluorescence (IF) for $\alpha 6$-integrin, a marker of basal polarity. Similar to the parental T4-2 cells, T4-2 ${ }^{\text {GFP }}$ cells transfected with shGFP formed disorganized colonies (Fig. 1F). Suppression of MMP9 allowed T4-2 cells to form polarized colonies, shown by basal localization of $\alpha 6$-integrin 
A

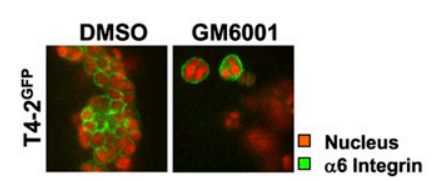

C

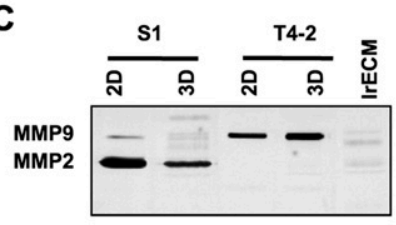

D

B

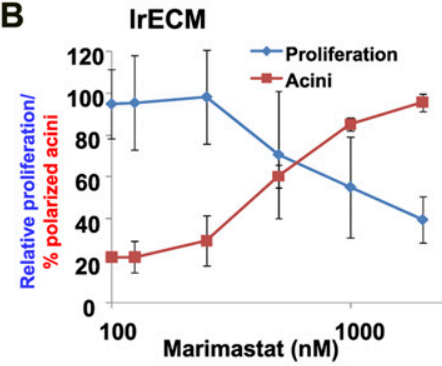

T4-2 2 vector

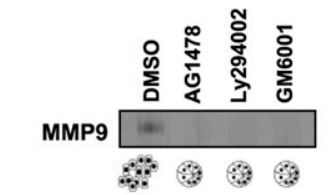

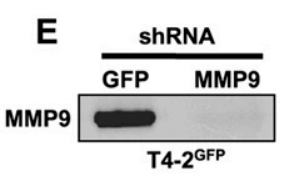

H

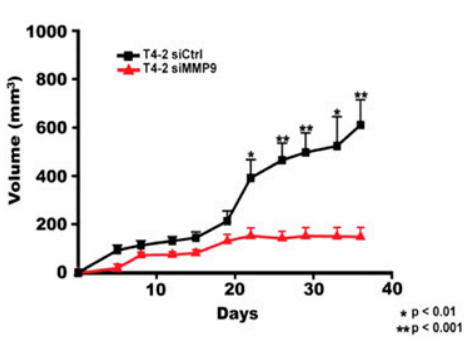

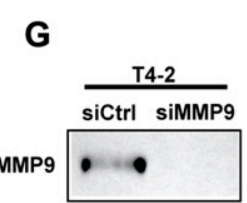

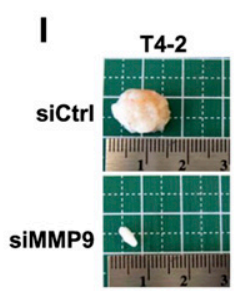

Figure 1. Suppression of MMP9 expression is sufficient to restore tissue architecture to HMT3522 T4-2 breast cancer cells in 3D 1rECM and inhibit tumor growth in vivo. (A) GM6001, a broad-spectrum MMP inhibitor, restores basal polarity visualized by $\alpha 6$-integrin IF. (Left) T4-2 3D cultures + DMSO. (Right) T4-2 + GM6001. (B) Treatment of T4-2 cells cultured in 3D lrECM with increasing concentrations of the MMP inhibitor Marimastat leads to decreased proliferation and increased colonies with basal polarity. Proliferation (blue) and polarized colonies (red) were normalized to untreated control. $(C)$ Zymography of CM. (Left) S1 cells produce MMP2 in both 2D and 3D, and a small amount of MMP9 only in 2D. (Right) T4-2 cells produce only MMP9. (Far right lane) Medium from cell-free lrECM dishes was used as the 1rECM control. $(D)$ Zymography of CM from 3D cultures of T4-2 treated with vehicle (DMSO), AG1478, LY294002, or GM6001. MMP9 levels decrease with phenotypic reversion. Loading was normalized to cell number using WST-1 reagent. (E) Zymography of CM from 3D cultures of T4-2 ${ }^{\mathrm{GFP}}$ cells transfected with either shGFP or shMMP9. shRNA to MMP9 down-modulates MMP9 production dramatically. $(F)$ Basal polarity ( $\alpha 6-$ integrin IF) is restored after down-modulation of MMP9. shGFP-transduced (left) and shMMP9-transduced (right) T4-2 cells in 3D 1rECM. More than $90 \%$ of colonies from shMMP9 T4-2 cells formed colonies with basal polarity. $(G)$ Zymography of CM from T4-2 cells transfected with scrambled or MMP9 siRNA. (H) Silencing of MMP9 reduces tumor growth significantly. T4-2 cells transfected with scrambled or MMP9 siRNA were injected in the rear flank of 6- to 8-wk-old female nu/nu mice. Tumor volume was measured every 2-3 d after injection. (I) Tumors were excised $5 \mathrm{wk}$ after injection due to the maximum allowable size in control mice. Tumor size of T4-2 cells with MMP9 siRNA (bottom) was much smaller compared with scrambled siRNA control (top).

(Fig. 1F; Supplemental Fig 1B), phenocopying the effect of the more broad-spectrum MMP inhibitor (Fig. 1A).

To test whether silencing MMP9 interfered with the ability of T4-2 cells to form tumors in a mouse xenograft model, T4-2 cells were transfected with scrambled siRNA (siCtrl) or siRNA against MMP9 (siMMP9). MMP9 silencing was confirmed by RT-PCR (data not shown) and zymography of CM (Fig. 1G). Cells were then injected subcutaneously in the rear flank of nu/nu mice. The tumor take for both T4-2 $2^{\text {siCtrl }}$ and T4-2 $2^{\text {siMMP9 }}$ was $>89 \%$; however, the tumors formed by the T4-2 $2^{\text {siMMP9 }}$ were significantly smaller compared with T4-2 $2^{\text {siCtrl }}$ cells (Fig. $\left.1 \mathrm{H}, \mathrm{I}\right)$. These data show that MMP9 is involved in the loss of tissue organization in T4-2 cells in 3D lrECM cultures and is necessary for tumor growth in vivo.

\section{MMP9 expression is controlled by Raf/MEK/ERK}

The demonstration that phenotypic reversion caused by inhibition of diverse pathways (Fig. 1D) reduced MMP9 levels and restored polarized morphology, and that tumor growth in vivo was dependent on MMP9, suggested that a shared central signaling axis might be involved. We showed previously that reversion of the malignant phenotype of T4-2 and other breast cancer cells correlated with attenuated signaling through the EGFR pathway (Wang et al. 1998, 2002; Kenny and Bissell 2007), suggesting that factors downstream from EGFR, such as MEK $1 / 2$, could be candidates for loss of signaling integration as cells become malignant. Regardless of the reverting agent used, restoration of T4-2 acinar morphology was associated with a significant down-modulation of EGFR, MEK1/2, and phospho-MEK1/2 (pMEK 1/2) (Fig. 2A), indicating that elevated activity of this pathway may be incompatible with polarized colony organization. Simultaneous transduction of T4-2 ${ }^{\mathrm{GFP}}$ cells with shRNAs against MEK1 and MEK2 down-modulated the expression of these molecules and their phosphorylated forms in $2 \mathrm{D}$ cultures by $\sim 50 \%$ compared with control shGFP (Fig. $2 \mathrm{~B}$ ). Interestingly, MEK1/2 knockdown was more pronounced in $3 \mathrm{D}$ cultures where pMEK $1 / 2$ was barely detectable by immunoblots of 3D cell lysates (Fig. 2B). Down-modulation of pMEK1/2 in $2 \mathrm{D}$ cultures appeared to have little effect on proliferation, as determined by plotting cumulative population doubling of shGFP- and shMEK1/ 2-transduced cells (Fig. 2C). However, the same cells showed a strikingly different behavior in 3D cultures. Control cells formed disorganized structures, whereas 
A

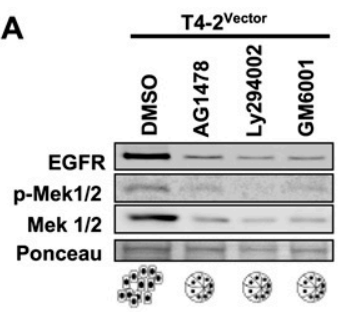

C

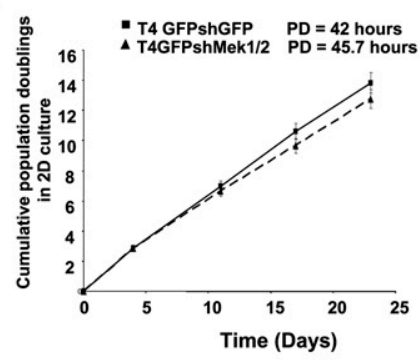

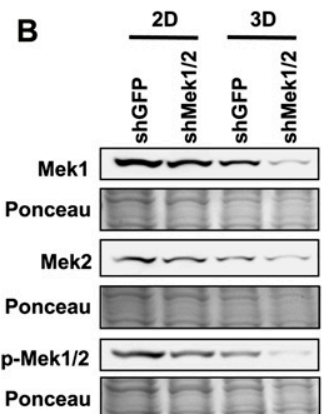

D

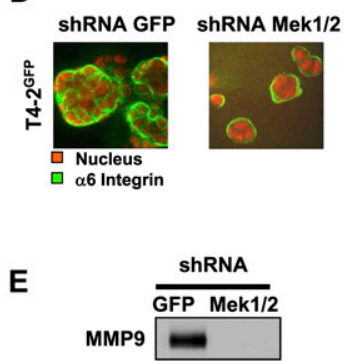

Figure 2. Attenuation of MEK activity results in inhibition of MMP9 expression and phenotypic reversion of the malignant T42 cells. (A) Immunoblots of total cell lysates from T4-2 $2^{\text {vector }}$ cells treated with indicated inhibitors for $7 \mathrm{~d}$ in 3D lrECM cultures. Phenotypic reversion of T4-2 cells is accompanied by decreased signaling through MEK. Ponceau-stained bands were used as a loading control. $(B)$ Immunoblot of total cell lysates from T4-2 ${ }^{\text {GFP }}$ cells transduced with control shGFP or with shRNAs against MEK1 and MEK2. Total level and the phosphorylated form of these two proteins are only slightly reduced in 2D cultures, but are significantly reduced in $3 \mathrm{D}$ cultures. Ponceau-stained bands were used as a loading control. $(C)$ Cumulative population doublings obtained from T4-2 $2^{\mathrm{GFP}}$ cells transduced with shGFP or shMEK1/2. Down-modulation of MEK1/2 does not significantly change proliferation in $2 \mathrm{D}$ cultures. $(D)$ shGFP- and shMEK1/2-transduced T4-2 ${ }^{\text {GFP }}$ cells maintained in 3D lrECM for $7 \mathrm{~d}$. Down-modulation of shMEK1/2 restores basal polarity. (Red) Nucleus; (green) $\alpha 6$-integrin. (E) Zymography of CM from 3D lrECM of shGFP-transduced (left) and shMEK1/2-transduced (right) T4-2 $2^{\mathrm{GFP}}$ cells. MMP9 production is lost with reversion induced by down-modulation of MEK1/2.

shMEK1/2 transduced cells formed organized colonies reminiscent of reverted T4-2 cells (Fig. 2D; Supplemental Fig. 1A,B). Importantly, MMP9 expression was abolished in T4-2 cells transduced with shMEK1/2 (Fig. 2E). Thus, down-modulation of Raf/MEK/ERK signaling is sufficient to inhibit MMP9 expression and induce formation of polar acini in T4-2 cells.

\section{Restoration of acinar morphology is blocked} by $M A P K$-induced MMP9 expression

To test the role of MEK and MMP9 activities in disruption of acinar morphogenesis directly, T4-2 cells were transduced with an inducible RafER construct (Samuels et al. 1993). RafER is a fusion of the constitutively active kinase domain of Raf-1 with the estrogen-binding domain of the human estrogen receptor (ER). The construct produces an

inactive protein that is activated by binding of $\beta$-estradiol or 4-hydroxytamoxifen to the ER domain, allowing temporal control of activation of the MAPK pathway (Fig. 3A). pMEK1/2 was used to monitor increased kinase activity achieved by induction of RafER. In the absence of $\beta$-estradiol, the level of pMEK1/2 in RafER-transduced T42 cells (T4-2 ${ }^{\text {RafER }}$ ) was similar to T4-2 cells transduced with empty vector (T4-2 $\left.{ }^{\text {vector }}\right)$. However, when T4-2 ${ }^{\text {RafER }}$ cells were treated with increasing concentrations of $\beta$-estradiol, pMEK1/2 was dramatically increased (Fig. 3B). Moreover, induction of RafER activity correlated with increased levels of MMP9, indicating that the Raf/MEK/ERK pathway regulates MMP9 (Fig. 3C).

To examine whether increased Raf/MEK/ERK activity was sufficient for resistance to reverting agents in $3 \mathrm{D}$ cultures, AG1478, Ly294002, and GM6001 were tested in T4-2 ${ }^{\text {vector }}$ and T4-2 $2^{\text {RafER }}$ cells. Each induced phenotypic reversion in T4-2 $2^{\text {vector }}$ cells, but induction of RafER activity abrogated the effect of these agents, preventing formation of organized polar colonies (Fig. 3D,E; Supplemental Fig. 2). Because MMP9 production was greatly increased when RafER was induced, we tested whether increased MMP activity was responsible for resistance to reversion when RafER was induced. Under these conditions, increasing GM6001 from the usual $40 \mu \mathrm{M}$ to $80 \mu \mathrm{M}$ allowed reversion even after RafER was induced (Fig. 3F, bottom row), indicating that resistance to GM6001-induced reversion of T4-2 $2^{\text {RafER }}$ cells was indeed due to increased MMP activity. Examination of EGFR signaling after RafER induction indicated that EGFR, MEK1/2, and pMEK1/2 levels remained high (cf. Figs. 3G and 2A) even in the presence of the reverting agents. Importantly, induction of RafER attenuated down-modulation of MMP9 (cf. Figs. $3 \mathrm{H}$ and 1D). These data clearly support the hypothesis that MAPK signaling disrupts T4-2 acinar morphology via MMP9 regulation, and illustrate that down-regulation of Raf/ MEK/ERK signaling is necessary to acquire proper epithelial architecture.

\section{Raf/MEK/ERK-induced MMP9 activity interferes with} acinar morphogenesis of nonmalignant cells in $3 D$

The strong correlation between the activity of the Raf/ MEK/ERK module, MMP9, and disruption of acinar polarity in malignant cells led us to test whether active Raf/MEK/ERK pathway and MMP9 activity were sufficient to disrupt the polarity of nonmalignant cells. We evaluated MEK activity in S1 and T4-2 cells grown in 3D lrECM on day 5 when S1 cells were still proliferating, and on day 10 when S1 cells had formed growth-arrested acini (Fournier et al. 2006). Total and pMEK1/2 levels were decreased significantly between days 5 and 10 in S1 cells in 3D lrECM cultures, whereas the expression and activity of MEK1/2 remained elevated in T4-2 (Fig. 4A).

To test directly whether high levels of MEK1/2 activity would disrupt morphogenesis in nonmalignant breast cells, S1 cells were transduced with either the RafER $\left(\mathrm{S} 1^{\text {RafER }}\right)$ construct or an empty vector control $\left(\mathrm{S}^{\text {vector }}\right)$. Induction of RafER in 2D cultures was followed by increased pMEK in a dose-dependent manner, confirming 

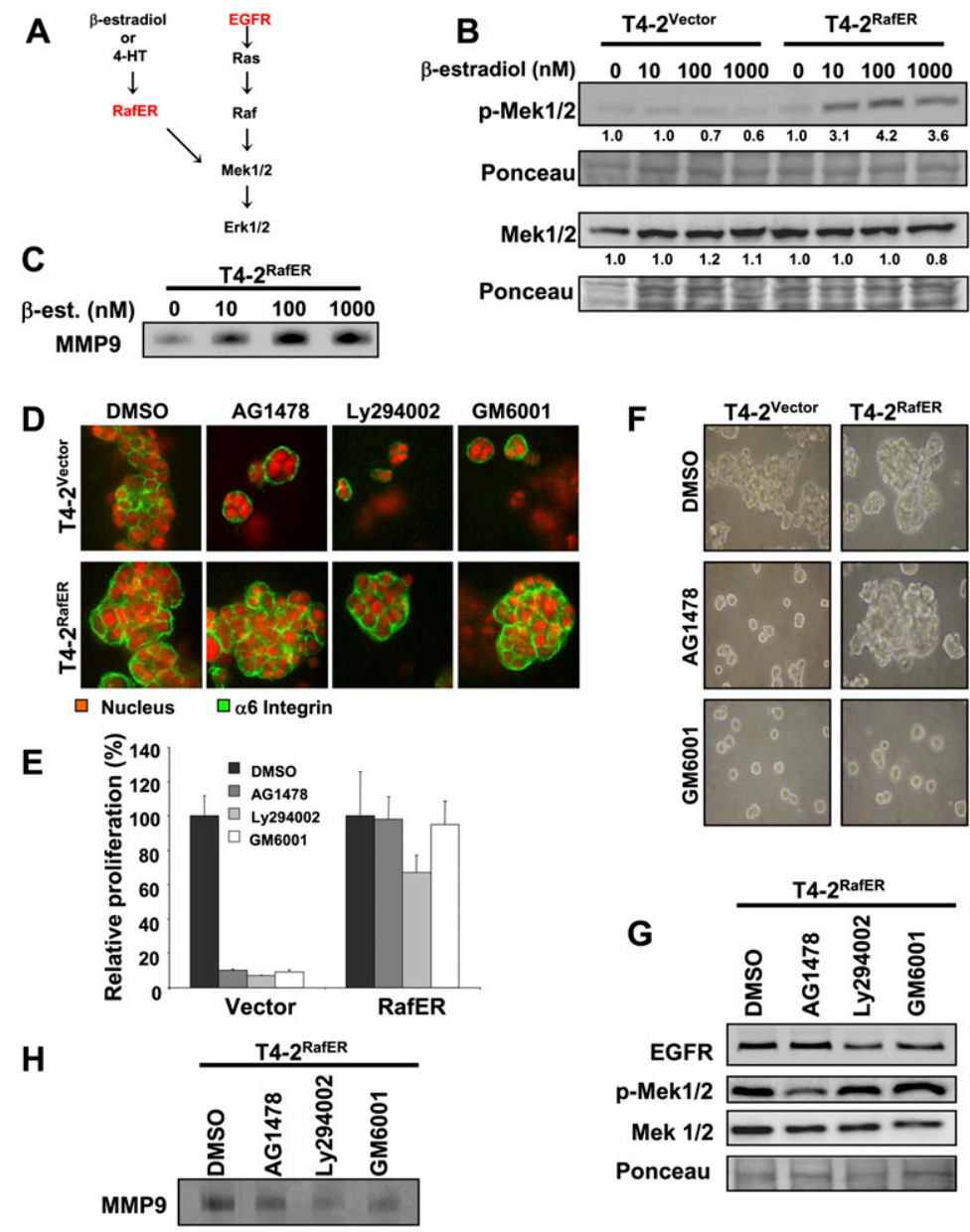

$\mathbf{F}$
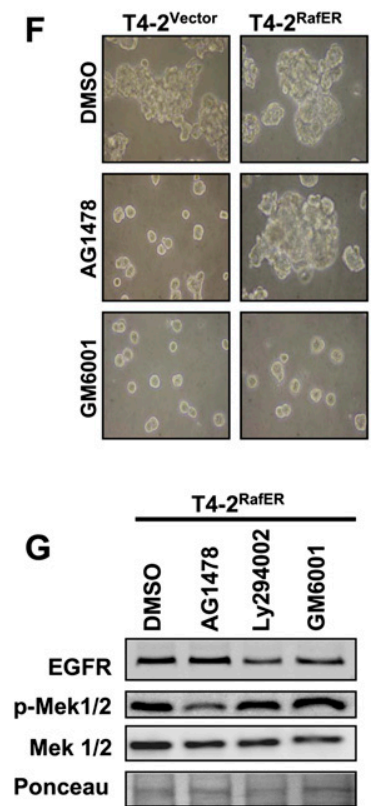

Figure 3. MAPK-induced MMP9 expression prevents phenotypic reversion of T4-2 cells induced by multiple inhibitors. (A) Schematic of Raf-MEK-ERK pathway. Ligand-induced activation of RafER bypasses upstream regulators, allowing temporal control of MEK activation. (B) Dose response of T4-2 ${ }^{\text {vector }}$ and T4-2 ${ }^{\text {RafER }}$ cells. Treatment with increasing concentrations of $\beta$-estradiol increases p-Mek-1 in the T4-2 ${ }^{\text {RafER }}$ in relation to control cells. Ponceau-stained bands indicate equal loading. $(C)$ Zymography of T4-2 RafER $\mathrm{CM}$. Increasing $\beta$-estradiol concentrations leads to increased levels of MMP9. $(D)$ T4-2 ${ }^{\text {vector }}$ and T4-2 ${ }^{\text {RafER }}$ cells were treated with DMSO, AG1478, LY294002, or GM6001 for $7 \mathrm{~d}$ in 3D 1rECM cultures and were stained for $\alpha 6$-integrin and DNA. T4$2^{\text {vector }}$ cells revert similar to wild-type T4-2 cells (top panel), whereas T4-2 RafER cells are resistant to reverting agents (bottom panel). (E) Histogram representing the relative proliferation of T4-2 $2^{\text {vector }}$ and T4-2 RafER cells determined by WST-1 reagent after $7 \mathrm{~d}$ in 3D lrECM. Proliferation of T4-2 $2^{\text {vector }}$ is significantly reduced by reverting agents, whereas $\mathrm{T} 4-2^{\text {RafER }}$ remains highly proliferative. $(F)$ Phase-contrast images of T4-2 vector and T4-2 ${ }^{\text {RafER }}$ cells treated with DMSO, AG1478, or a higher concentration of GM6001 $(80 \mu \mathrm{M}$ compared with $40 \mu \mathrm{M}$ used in $D$ for $7 \mathrm{~d}$ in $3 \mathrm{D}$ lrECM. Cells remain resistant to reversion by AG1478, indicating that RafER is active. Increasing the concentration of GM6001 counteracts the action of activated RafER observed in $D$ and leads to reversion of T4-2 ${ }^{\text {RafER }}$. $(G)$ Immunoblot analysis of total cell lysates from 3D lrECM cultures of T4-2 ${ }^{\text {RafER }}$ cells treated with indicated inhibitors. EGFR and p-Mek-1 levels remain elevated even in the presence of the reverting agents. Total Mek levels remain unchanged. Immunoblot of total cell lysates from 3D lrECM cultures of control T4-2 $2^{\text {vector }}$ is presented in Figure $2 \mathrm{~A}$ and indicates that phenotypic reversion is accompanied by a decrease in signaling through Mek. Ponceau-stained protein bands indicate equivalent sample loading. $(H)$ Zymography of CM collected from T4-2 ${ }^{\text {RafER }}$ cells treated with DMSO, AG1478, Ly294002, or GM6001 in 3D lrECM shows that MMP9 production remains elevated in the presence of the reverting agents due to continued signaling through the MEK pathway. Zymography of CM collected from control T4-2 $2^{\text {vector }}$ cells is presented in Figure 1D. Loading was normalized to cell number, as determined by WST-1 reagent.

RafER function (Fig. 4B). As expected, the level of MMP9 was increased upon RafER induction in S1 cells (data not shown). Because neoplasia arises generally within the context of an already polarized epithelium, we investigated whether activation of the Raf/MEK/ERK pathway could induce growth and/or disorganization in quiescent, preformed acini. S1 cells transduced with RafER were grown in $3 \mathrm{D}$ lrECM for $10 \mathrm{~d}$ in the absence of $\beta$-estradiol, by which time they had formed organized acini. This was followed by $\beta$-estradiol induction of RafER for another 10 d (Fig. 4C). S1 ${ }^{\text {RafER }}$ cells maintained a polarized structure in the absence of $\beta$-estradiol, as shown by maintenance of $\alpha 6$-integrin around the basal surface of the acini. In contrast, $\beta$-estradiol treatment from day 10 to day 20 resulted in colonies with irregular structures, where the pattern of $\alpha 6$-integrin was disrupted and distributed around individual cells throughout the colonies. The $\mathrm{CM}$ from these disorganized colonies contained increased MMP9 levels (Fig. 4D). These experiments demonstrate that Raf/MEK/ERK activity is tightly and directly regulated in nonmalignant breast epithelial cells, and that loss of this control is sufficient to disrupt epithelial organization.

Whereas these data demonstrate a key role for Raf/MEK/ ERK in disruption of epithelial polarity in nonmalignant cells, evidence for the specific role of MMP9 as an agent of acinar disorganization could still be off-target. To unequivocally assess the effect of MMP9 on acinar morphogenesis, we engineered a mutant MMP9 that could be activated, specifically and conditionally, by addition of a recombinant protease to the culture, leading to activation of latent MMP9. We introduced an enterokinase (EK) cleavage site into the MMP9 coding sequence at the junction between the propeptide and the catalytic domain (Fig. 5A). EK is a serine protease commonly used to cleave epitope tags fused to recombinant proteins (Jenny et al. 2003). The cleavage site is relatively rare in mammalian proteins, making it a useful and specific "switch" for the purpose here. The resulting inducible MMP9 (MMP9 ${ }^{\mathrm{EK}}$ ) construct was transduced into S1 or MCF10A cells, another 
A
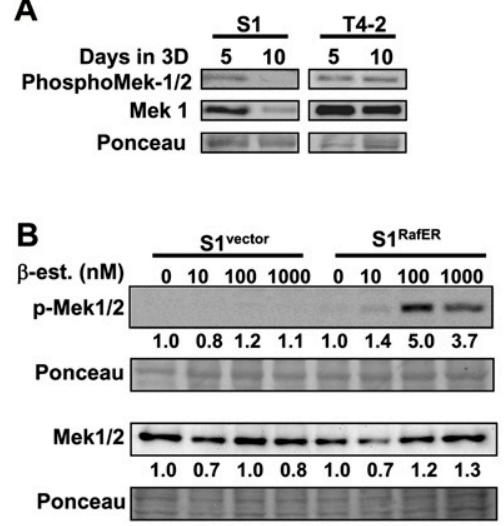

C

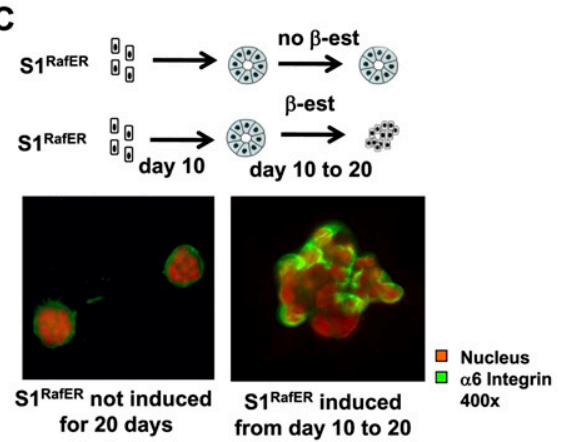

Figure 4. Expression of RafER in nonmalignant human breast cells in 3D culture disrupts epithelial architecture. (A) Immunoblot of total cell lysates from S1 and T4-2 cells cultured for 5 or $10 \mathrm{~d}$ in $3 \mathrm{D}$ lrECM shows that Mek-1 protein levels and p-Mek-1 levels decrease in S1 cultures by day 10. In contrast, protein levels of Mek-1 and pMek-1 in T4-2 cells remain high even at day 10 in $3 \mathrm{D}$ cultures. $(B)$ Immunoblot of total cell lysates from S1 cells transduced with empty vector or RafER. Treatment for $48 \mathrm{~h}$ with increasing concentrations of $\beta$-estradiol results in increased pMEK-1 levels in the RafER-transduced cells. Treatment did not change Mek1/2 total protein levels. (C) RafER-transduced S1 cells were maintained in lrECM 3D cultures for $10 \mathrm{~d}$ in the absence of RafER induction to allow formation of quiescent polar colonies. Cultures were then treated for an additional $10 \mathrm{~d}$ with either vehicle (left panel) or $\beta$-estradiol (right panel) to induce RafER. Induction of RafER disrupted the established basal polarity shown by $\alpha 6$-integrin IF. $(D)$ Zymography of CM from the cultures shown in $C$. Induction of RafER increases the MMP production.

nonmalignant human mammary cell line capable of forming basally polarized acini in 3D lrECM (Petersen et al. 1992). Addition of EK led to accumulation of the cleaved form of MMP9 in the CM, as demonstrated by zymography showing a shift in molecular weight of MMP9 as a function of EK concentration (Fig. 5B). S1 and MCF10A cells expressing MMP9 ${ }^{\mathrm{EK}}$ or empty vector were allowed to form structures in 3D cultures, followed by addition of EK to the cultures. Activation of MMP9 in situ dramatically disrupted basal polarity of the preformed acini in both S1 ${ }^{\text {MMP9EK }}$ and MCF10A ${ }^{\text {MMP9EK }}$ cells, whereas vector-transduced cells remained polarized (Fig. $5 \mathrm{C}, \mathrm{D})$. These experiments demonstrate that unscheduled
MMP9 activity can disrupt acinar polarity even in nonmalignant human breast cells.

MMP9 activity targets LM1, a critical component of the basement membrane (BM), for formation and maintenance of acinar morphogenesis in vivo and in $3 D$ cultures

To identify potential MMP9 substrates responsible for the phenotype observed in 3D cultures, supernatants were harvested from (1) 3D cultures of $S 1^{\text {MMP9EK }}$ cells cultured in the presence of EK to activate MMP9 with or without the MMP inhibitor Marimastat (BB2516), and (2) 3D cultures of $S 1^{\text {MMP9EK }}$ cells treated with or without EK. Parallel experiments were conducted in MCF10A ${ }^{\text {MMP9EK. }}$. CMs were concentrated and digested with trypsin, and $\mathrm{N}$ termini were labeled with isobaric mass tags (TMT) to quantify the relative abundance of individual peptides by LC-MS/MS. The ratio of peptides identified in EK-activated MMP9 samples with or without BB2516 (Fig. 6A, column A) and the ratio of peptides identified in unactivated versus EK-activated MMP9 (Fig. 6A, column B) were derived from the intensity of TMT reporter ions (for instance, with BB2516 $\mathrm{TMT}^{127} /$ without BB2516 $\mathrm{TMT}^{128}$ ). Results revealed several peptides corresponding to the three subunits of the LM1 molecule $(\alpha 1, \beta 1$, and $\gamma 1)$ accumulated in CM of S1 cells where MMP9 was active (Fig. 6A,B). A ratio $<0.5$ corresponds to a large accumulation, and a ratio between 0.5 and 0.8 corresponds to a mild accumulation of LM1 subunit peptides in the CM in response to MMP9 activity (Fig. 6A). Importantly, we identified $\mathrm{N}$ termini indicative of MMP cleavage, suggesting that some of the $\mathrm{N}$ termini labeled with TMT resulted from direct cleavage by cell-derived MMP rather than by trypsin used to prepare the sample prior to TMT labeling and LC-MS/MS analysis. An example of a peptide identified from the CM is shown in Figure 6B. The MS/ MS spectrum indicating $\mathrm{TMT}^{126}$ modification on the $\mathrm{N}$ terminus of the peptide and the intensity of the TMT reporter ions are shown to demonstrate the disappearance of this peptide in the presence of the MMP inhibitor $\left(\mathrm{TMT}^{127}\right)$ or the CM without MMP9 activity (TMT $^{128}$, background). Similar results were obtained for MCF10A ${ }^{\text {MMP9EK }}$ cells (Supplemental Table 1). The fact that LM1 was identified as a substrate in both cell lines suggests that it is indeed a physiological target of MMP9.

To address whether LM1 is a substrate of MMP9 in vivo, tissue sections from T4-2 $2^{\text {siCtrl }}$ and T4- $2^{\text {siMMP9 }}$ tumor xenografts were probed with an antibody specific for human LM1. Results revealed that human LM1 was considerably more abundant in T4-2 ${ }^{\text {siMMP9 }}$ than in T4$2^{\text {siCtrl }}$ (Fig. 7); thus, the presence of LM1 correlates inversely with the ability of T4-2 ${ }^{\text {siMMP9 }}$ cells to grow large tumors in this model (Fig. 1H,I). These results suggest also that LM1 is a target of MMP9 in vivo. Our data directly confirm the importance of LM1 in formation of acini in 3D assays, and show additionally that LM1 is a physiological substrate of MMP9 both in culture and in vivo. These results shed further light on how loss of myoepithelial cells, which are the source of LM1 in vivo 
A

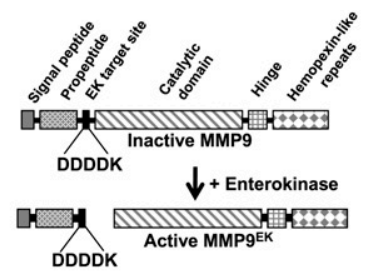

B

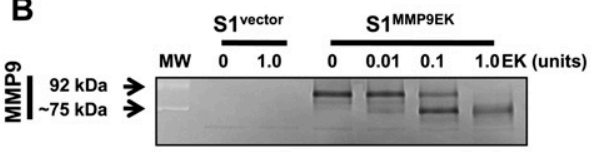

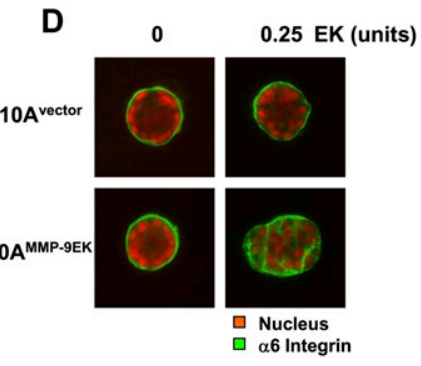

Figure 5. Induction of MMP9 activity is sufficient to disrupt mammary epithelial acinar organization in nonmalignant breast cells. (A) Schematic of the mutant $\mathrm{MMP}^{\mathrm{EK}}$ showing localization of the EK cleavage site and the generation of active MMP9 following digestion. (B) Zymography of CM from S1 cells transduced with $\mathrm{MMP}^{\mathrm{EK}}$ or empty vector grown in $3 \mathrm{D} \operatorname{lrECM}$ for 3 $\mathrm{d}$ and then treated with $0,0.01,0.1$, and $1.0 \mathrm{U}$ of EK for 4 $\mathrm{d}$ shows that EK addition leads to MMP9 activation in $\mathrm{S}^{\mathrm{MMPOEK}}$, as indicated by the appearance of a $75-\mathrm{kDa}$ band corresponding to the molecular weight of active MMP9. Arrows indicate the latent $92-\mathrm{kDa}$ and $\mathrm{EK}-$ generated $75-\mathrm{kDa}$ form of active MMP9. (C) IF of $\mathrm{S1}^{\text {vector }}$ and $\mathrm{S1}^{\text {MMP9EK }} 3 \mathrm{D}$ cultures treated with EK shows that vector control cells form colonies with basal polarity, whereas $33 \%$ of $\mathrm{S} 1^{\mathrm{MMP} E \mathrm{EK}}$ colonies are disorganized, as shown by $\alpha 6$-integrin IF. (D) IF of MCF10A ${ }^{\text {vector }}$ and MCF10A ${ }^{\text {MMP9EK }} 3$ D cultures treated with EK shows that vector control cells form colonies with basal polarity, whereas a subpopulation ( 30\%) of MCF10A ${ }^{\text {MMP9EK }}$ fail to establish a proper basal polarity, as determined by $\alpha 6$-integrin IF. in the mammary gland (Gudjonsson et al. 2002), could contribute to breast tumor progression, and may explain the aggressiveness of MMP9-expressing tumors in vivo (Li et al. 2004; Vizoso et al. 2007).

\section{Discussion}

Perturbations in tissue structure have long been used by pathologists as early hallmarks of cancer. How the central regulators of tissue specificity and structure are unraveled in tumors, however, has remained a challenge. Using a robust 3D culture model that approximates formation of mammary acini, we show that a hyperactive Raf/MEK/ ERK pathway leads to increased MMP9, which destroys tissue polarity and growth control. MMP9 achieved this end through proteolysis of LM1, leading to destruction of BM integrity. Inhibition of the pathway to levels found in nonmalignant cells suppressed MMP9, leading to phenotypic reversion, growth arrest, and re-establishment of acinar polarity. Inhibition of MEK or MMP9 by pharmacological inhibitors or shRNAs restored acinar morphology to cancer cells in 3D cultures. Furthermore, in a murine xenograft model, silencing of MMP9 expression resulted in a significant inhibition of tumor growth and an impressive increase in LM1 in the residual tumor. The current data show that loss of LM1 integrity by MMP9 activity due to a hyperactive Raf/MEK/ERK pathway leads to malignant progression (Fig. 8).

Using supraphysiological levels of EGF in 2D culture, MMP9 levels were shown to increase in T4-2 cells (Price et al. 2002). Both basal breast cancer cell lines such as MDA-MB 231 and luminal cell lines such as MCF-7 were shown to secrete MMP9 in response to ERK1/2, which suggests that the interplay between ERK1/2 and MMP9 is not limited to T4-2 cells (Liu et al. 2002; Tsai et al. 2003;
Byun et al. 2006; Zhang et al. 2006). The many roles of ERK1/2 activation in promoting cell proliferation have been studied widely. By phosphorylating a large number of cytoplasmic, membranous, and nuclear substrates, ERK stimulates cell cycle progression at multiple levels (Meloche and Pouyssegur 2007). However, many of the studies have been performed on tissue culture plastic or other 2D substrata where cells are not subject to the same rules imposed in vivo, or in $3 \mathrm{D}$ cultures where tissue architecture itself exerts a potent anti-proliferative effect (Petersen et al. 1992; Bissell et al. 2005; Fournier et al. 2006; Pugacheva et al. 2006; Halbleib et al. 2007; Wodarz and Nathke 2007).

The 3D lrECM assays have allowed a mechanistic exploration of the interplay between tissue architecture and proliferation. Under these conditions, nonmalignant HMECs down-regulate the expression of EGFR and stop proliferating, even in the presence of EGFR ligands, once the polarized acini are formed (Petersen et al. 1992; Wang et al. 1998; Fournier et al. 2006). Here, we demonstrate that the ability of the nonmalignant S1 cells to form acini, or the ability of malignant T4-2 cells to "revert," is contingent on down-regulation of Raf/MEK/ERK or MMP9 activities. Raf activation was reported to interfere with acinar morphogenesis of MCF10A by promoting cellular motility within organized colonies (Pearson and Hunter 2009). Induction of ErbB2 was shown to destroy the architecture of preformed MCF10A acini (Muthuswamy et al. 2001) in a manner that resembled induction of MMP9 or Raf activity shown here. Whereas the activity of the MEK pathway is closely associated with increased proliferation, phenotypic reversion of T4-2 cells or formation of nonmalignant acini is not simply due to a change of proliferative status. Expression of viral or cellular oncogenes in nonmalignant S1 and MCF10A cells in 3D promoted 
A

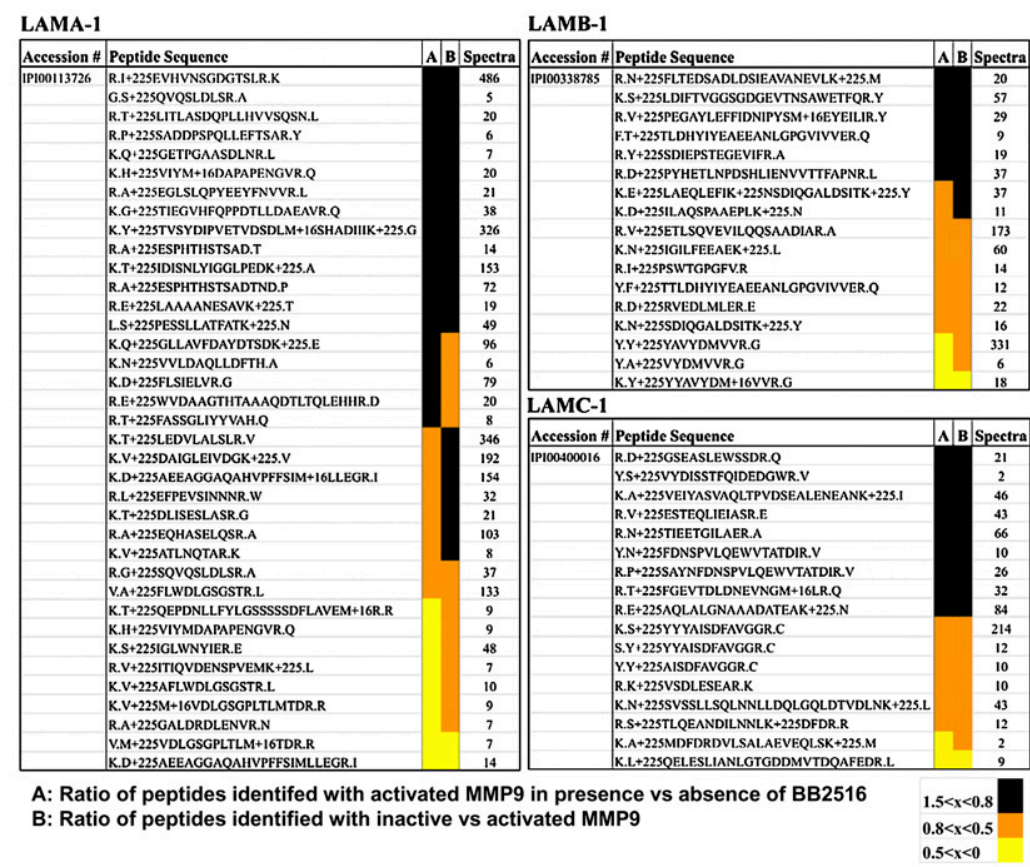

B

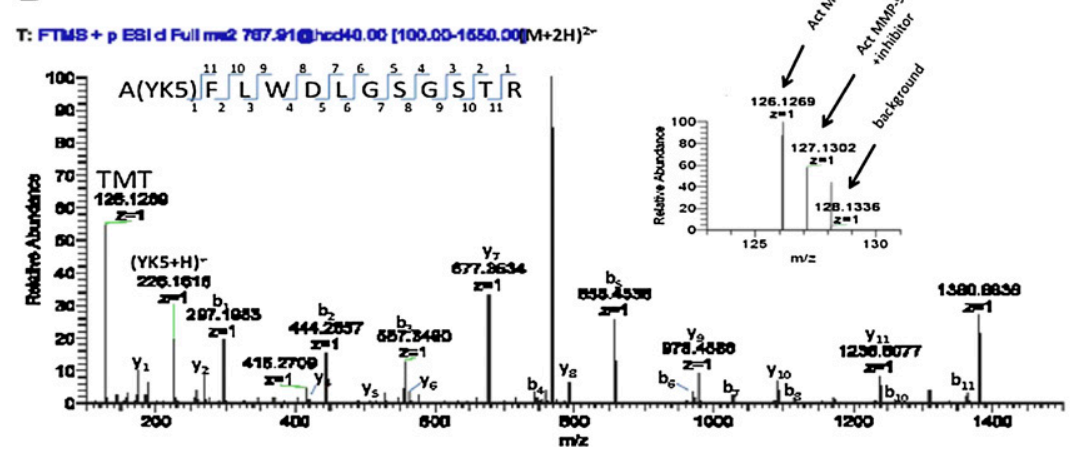

Figure 6. LC-MS/MS analysis of S1 cell CM in the presence or absence of active MMP9 reveals that LM1 is a substrate for MMP9 in 3D cultures. (A) List of peptides corresponding to fragments of LAMA-1, LAMB-1, and LAMC-1 identified by LC-MS/MS analysis in CM harvested from 3D cultures of $S 1^{\text {MMP9EK }}$ cells cultured in the presence of EK to activate MMP9 and with or without the MMP inhibitor Marimastat (BB2516), or from 3D cultures of $\mathrm{S1}^{\mathrm{MMP9EK}}$ cells with or without EK treatment to activate MMP9. Quantification was derived from the intensity of TMT reporter ions. For each peptide, the ratio of peptide found in the CM containing EK-activated MMP9 with or without BB2516 or in CM containing inactive MMP9 versus EKactivated MMP9 is shown in columns $\mathrm{A}$ and $B$, respectively. Dark yellow illustrates a ratio between 0.8 and 0.5 , corresponding to mild accumulation of peptide associated with active MMP9. Light yellow illustrates a ratio $<0.5$ and corresponds to a more significant accumulation of peptides associated with active MMP9. (B) An example of TMT-modified peptide with MMP9 cleavage specificity. The tandem mass spectrum is presented to demonstrate TMT modification at the $\mathrm{N}$ terminus of the peptide. (Inset) Reporter ion chromatogram used to quantify the reduction of this peptide in the presence of BB2516 is also shown. proliferation but failed to disrupt basal polarity (Spancake et al. 1999; Debnath et al. 2002; Weaver et al. 2002). The data reported here demonstrate that, in addition to its multiple effects on the cell cycle machinery and proliferation, activation of Raf/MEK/ERK perturbs tissue architecture via MMP9 induction and degradation of LM1, thereby destroying the key restraining effect of this BM component on both tissue polarity and proliferation.

Mice deficient in expression of MMP9 were less susceptible to experimentally induced metastasis (Itoh et al. 1999; Acuff et al. 2006) and had greatly reduced tumor incidence when crossed with the HPV16 skin (Coussens et al. 2000) or RIP1-TAG2 pancreatic (Bergers et al. 2000) cancer models. Whereas MMTV-PyMT mice deficient for MMP9 did not show a change in the occurrence of multifocal mammary tumors, formation of lung metastases was reduced significantly (Martin et al. 2008). Increased MMP9 levels correlate also with an increase in metastatic disease and reduced relapse-free survival in patients with breast cancer (Li et al. 2004; Vizoso et al. 2007; Wu et al. 2008). Data from other laboratories suggest an important role for MMP9 in human tumor progression in several additional organs (Bloomston et al. 2002; Roy et al. 2008). Expression of MMP9 along with a number of other molecules was shown recently to constitute
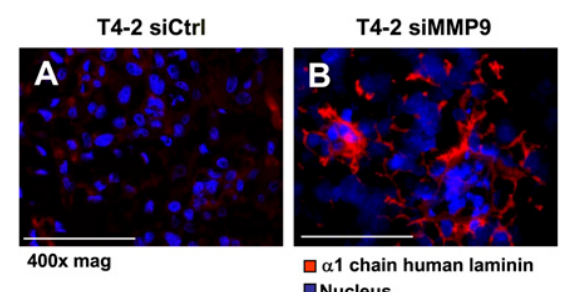

Figure 7. Reduction of MMP9 expression in T4-2 cells correlates with increased levels of human LM $\alpha 1$ chain in xenografted tumors. Tumor sections from T4-2 cells transfected with scrambled siRNA $(A)$ or MMP9 siRNA $(B)$ probed for human LM $\alpha 1$ chain show more LM1 in the tumors where MMP9 was silenced, suggesting that decreased MMP9 activity preserves LM1. Images are shown at the same magnification. Nuclei are shown in blue, and LM is shown in red. 


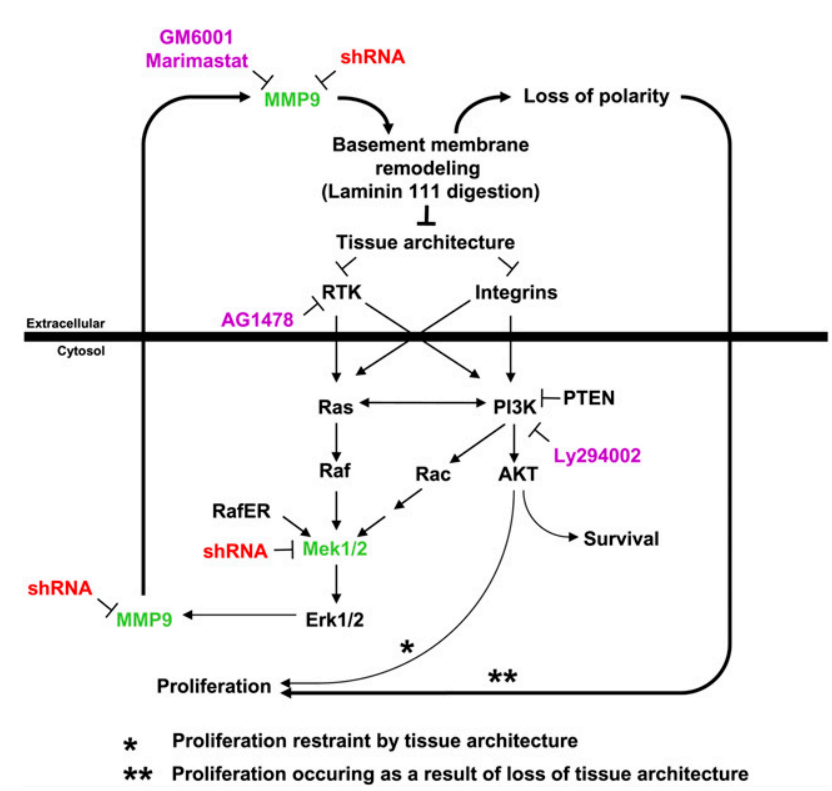

Figure 8. Scheme illustrating the dynamic reciprocity between MMP9 and the Raf-MEK-ERK pathway, which determines whether cells would continue to proliferate or undergo acinar morphogenesis. Culture of HMECs on 3D lrECM allows formation of polarized acini and reduction in proliferation. Increased Raf-MEK-ERK pathway induces MMP9 expression, which in turn prevents the formation of basal polarity by promoting the remodeling of the BM through the proteolysis of LM1. Inhibition of MMP9 activity with chemical inhibitors (GM6001 or Marimastat) or shutting down MMP9 expression directly with shRNA allows acinar polarization. Down-modulation of the MAPK pathway directly with shRNA to MEK1/2 or indirectly by inhibition of EGFR (AG1478) or PI3K (LY294002) allows the cells to integrate the proper signaling pathways and promotes acinar polarization. The result of proper modulation of the MAPK signaling pathway during acinar formation is to reduce the levels of MMP9, thereby protecting the integrity of ECM proteins, feeding back the appropriate signals to maintain tissue homeostasis. (RTKs) Receptor tyrosine kinases; (mRTKLs) membrane-bound RTK ligands; (sRTKLs) soluble RTKLs.

a signature for predicting resistance to drug therapy in ovarian cancer (M Gottesman, pers. comm.). Using a murine xenograft model, we now show that silencing MMP9 expression in T4-2 cells reduced their ability to form tumors significantly when injected in the rear flank of nu/ nu mice; this inhibition was directly correlated with an increase of human LM1 in the residual tumors.

Historically, studies have associated MMP9 activity mainly with increased invasion and metastatic property of tumors; our data reveal that MMP9 may be involved also in an earlier step associated with loss of tissue architecture. LC-MS/MS analysis performed on CM from S1 and MCF10A cells in 3D assays with or without MMP9 activity revealed that LM1 is targeted. Several studies from our group have addressed the importance of LM1 in the establishment of polarized acini in 3D lrECM. It is indeed the LM1 component in Matrigel that allowed us to develop the first 3D acinar assays with primary mouse cultures, and to show its requirement for induction of $\beta$-casein expression (Barcellos-Hoff et al. 1989; Streuli et al. 1991). It is only when a LM1-rich endogenous BM is formed in floating collagen gels that mammary cells become polar and express $\beta$-casein (Streuli and Bissell 1990). Primary cultures of human luminal cells fail to form acini inside a pure collagen I gel because, in this "stiff" microenvironment (Alcaraz et al. 2008), tissue polarity is reversed, but correct acinar morphogenesis could be rescued when LM1 is added to collagen I gels (Gudjonsson et al. 2002). We also provided evidence that LM1 signals to transcription factors (Streuli et al. 1991; Xu et al. 2009), most probably via an ECM response element in the promoter of the $\beta$-casein gene (Schmidhauser et al. 1992; Myers et al. 1998). It is thus clear that LM1 provides the biochemical and mechanical cues for acinar morphogenesis and functional differentiation. These observations and the current results support the conclusion that MMP9 activity perturbs the microenvironmental cues that integrate acinar architecture (in particular the LM1 component of the BM), contributing directly to the loss of tissue polarity observed in 3D cultures of T4-2 cells and in the nonmalignant S1 and MCF10A in the presence of active MMP9. Once the architecture is disturbed continuously, the cells produce reactive oxygen species and undergo epithelial mesenchymal transition and genomic instability on their way to becoming malignant (Radisky et al. 2005).

Despite the evidence that MMPs do play important roles in cancer, targeting them with broad-spectrum single-agent inhibitors has proven problematic in clinical trials (Zucker et al. 2000; Coussens et al. 2002). Although these trials have diminished enthusiasm for MMP-targeted drugs substantially, most of the studies were performed in patients with advanced and treatment-refractory metastatic disease (Coussens et al. 2002). Moreover, our knowledge of MMP function in cancer and the large number of roles that these enzymes play in development and homeostasis was still wanting (Page-McCaw et al. 2007). As the distinct functions of different MMPs are better understood in both health and disease, the possibility of selectively targeting key MMPs involved in pathogenesis is gaining attention again (Overall and Kleifeld 2006). Studies to identify key substrates in promoting tumorigenesis and malignant progression may additionally guide therapeutic approaches, including the selection of patients at appropriate stages of disease and the identification of biomarkers by which the efficacy of clinical trials could be assessed. Equally important are implications of correct tissue polarity and the need for suppression of the Raf/MEK/ERK pathway and MMPs to allow maintenance of tissue-specific architecture in both homeostasis and premalignant lesions.

\section{Materials and methods}

\section{Cell culture}

S1 and MCF10A cells (American Type Culture Collection [ATCC]) were maintained in 2D and 3D in H14 medium with EGF, and T42 cells were maintained in H14 medium without EGF (Weaver et al. 1997). For 3D 1rECM culture, T4-2 cells were seeded at 21,000 cells per square centimeter, whereas S1 and MCF10A cells were seeded at 28,000 cells per square centimeter on top of lrECM 
(BD Biosciences or Trevigen) (Lee et al. 2007). In various experiments, supplements were used at the following concentrations: 10 $\mathrm{nM} \beta$-estradiol in phenol red-free medium, 70 nM AG1478, $7 \mu \mathrm{M}$ Ly294002, $40 \mu \mathrm{M}$ GM6001, or the relevant vehicle controls. Population doublings (PD) per passage was determined by $\mathrm{PD}=$ $(\mathrm{A} / \mathrm{B}) / \log 2$, where A represented the number of harvested cells, and $\mathrm{B}$ represented the number of plated cells. Activation of MMP9 $9^{\mathrm{EK}}$ was performed by adding EK (Invitrogen) to culture medium. S1and MCF10A-transduced cells were kept in culture for 4 or $14 \mathrm{~d}$, respectively. Medium \pm EK was changed every $48 \mathrm{~h}$.

\section{Immunoblot and IF}

Antibodies were purchased from Cell Signaling Technology, except EGFR (BD Biosciences) and $\alpha 6$-integrin (Chemicon), and were used at the manufacturers' suggested concentrations. Lysates were prepared in $4 \%$ SDS, $20 \%$ glycerol, and $0.125 \mathrm{M}$ Tris (pH 6.8) with protease inhibitor cocktail (set III, Calbiochem) and phosphatase inhibitor cocktail (set II, Calbiochem). Forty-microgram samples were resolved on $10 \%$ polyacrylamide gels, transferred to nitrocellulose, and probed using chemiluminescence (Pierce). For IF, cells were cultured on lrECM in chamber slides and fixed with 1:1 methanol/acetone. Slides were incubated with primary antibody, followed by Alexa 480-conjugated secondary antibody, and were visualized by confocal microscopy.

\section{Immunohistochemistry}

Tumors were fixed in $2 \%$ paraformaldehyde overnight at $4^{\circ} \mathrm{C}$. Paraffin embedding and sectioning $(4 \mu \mathrm{m})$ were performed by the University of California at San Francisco Core. Antigen retrieval was achieved via proteinase $\mathrm{K}$ treatment. Sections were blocked in $10 \%$ goat serum in PBS and incubated with LM $\alpha 1$ humanspecific monoclonal antibody (clone EB7; gift from Ismo Virtanen). Primary antibody was revealed using an AlexaFluor 568 (Invitrogen) secondary antibody. Sections were stained with DAPI and imaged on a Zeiss microscope.

\section{Viral transduction}

Cells were infected with pBABEPuro retrovirus containing the $\triangle$ Raf-1:ER or with a construct containing only the human binding domain of ER (HbER). T4-2 cells were stably transduced with pMSCV-GFP-expressing retrovirus to create the T4-2 ${ }^{\text {GFP }}$ cell line. T4-2 ${ }^{\text {GFP }}$ cells were coinfected with pLenti-RNAi-Puro-expressing short hairpins targeting human MEK1 (siMEK1, ATGACGACTT TGAGAAGAT) and MEK2 (siMEK2, GGTCGGCGAACTCAAA GAC) or containing shRNA against GFP as control. shRNA sequences for MEK1 and MEK2 were selected from three and two different sequences for their efficacy to down-modulate MEK1 and MEK2. S1 and MCF10A cell lines were infected with pLentiCMV/ TO-Puro empty or containing the MMP9 ${ }^{\mathrm{EK}}$ mutant cDNA.

\section{shRNA and siRNA transfection}

T4-2 cells were transfected with pSUPER-RETRO-expressing short hairpin targeting human MMP9 (si-MMP9, CATCACC TATTGGATCCAA) (Sanceau et al. 2003) using Lipofectamine 2000. For in vivo injection into nu/nu mice, T4-2 cells were transfected with siRNA at $300 \mathrm{nM}$ against MMP9 (Ambion ID 113183) or scrambled control using siPORT NeoFX (Ambion).

\section{Tumor formation in vivo}

Tumor growth in vivo was evaluated by subcutaneously injecting the rear flank of 6- to 8-wk female nu/nu mice (Jackson
Laboratories) with 2.5 million T4-2 cells transfected with scrambled or MMP9 siRNA in 50\% Matrigel. Tumor growth was evaluated biweekly with a caliper and the inferred volume was graphed. The experiment was stopped and tumors were harvested when controls reached $1 \mathrm{~cm}^{3}$. Statistical analysis of the mean tumor volumes was done by pairwise comparison using one-tailed homoscedastic $t$-test analysis.

\section{Zymography}

Zymography was performed according to Herron et al. (1986). Samples were loaded normalized to cell number, as determined by WST-1 reagent (Roche). Dried gels were scanned and the image was inverted.

\section{Preparation of the secreted protein for mass spectrometry} $S 1^{\text {vector }}$ and $\mathrm{S}^{\mathrm{MMP}}{ }^{\mathrm{MEK}}$ treated with $0.25 \mathrm{U}$ of EK were kept in 3D culture for $14 \mathrm{~d}$ and medium was collected every $48 \mathrm{~h}$. Medium for each cell line was pooled and concentrated with an Ultra-4 centrifugal filter unit with Ultracel-3 membrane (Amicon). MCF10A cells were treated similarly.

\section{Mass spectrometry analysis}

Fifty micrograms of protein from CM was digested in $50 \mathrm{mM}$ TEAB (provided by the TMT 6plex kit, Thermo Fisher) and $2 \mathrm{mM}$ $\mathrm{CaCl}_{2}$ by trypsin $(2.5 \mu \mathrm{g}$ of trypsin [1:20 protease to substrate ratio] for each sample), and the reaction was incubated for $16 \mathrm{~h}$ at $37^{\circ} \mathrm{C}$. See the Supplemental Material for detailed method for analysis.

\section{Acknowledgments}

We thank Tarlochan Niijar for the pSUPER-RETRO-GFP, Eric Campeau for the MEK1-2 shRNA design, Lynn Weir for technical help, and Paraic Kenny, Roland Meier, Cyrus Ghajar, and Irene Kuhn for helpful comments. This work was supported by a Distinguished Fellow Award and grants from the Office of the Biological and Environmental Research of the US Department of Energy (US-DOE; DE-AC02-05CH11231), Low-Dose Radiation Program of the Office of Health and Environmental Research, Health Effects Division, US-DOE (03-76SF00098), an Innovator award from BCRP of the Department of Defense (USDOD; W81XWH0810736), and the National Cancer Institute (NCI; awards R37CA064786, U54CA126552, R01CA057621, U54CA112970, U54CA143836, and U01CA143233). E.I.C. was supported by a Susan Komen Catalyst Research Grant and the shared instrument grant (NIH/NCRR 1 S10 RR023680-1). A.B. was the recipient of fellowships from "Fonds pour la Formation de Chercheurs et l'Aide à la Recherche" and the Canadian Institutes of Health Research. J.D.M. was supported by R01CA088858 from NCI, and J.M. was supported by R01CA109579 from NCI.

\section{References}

Acuff HB, Carter KJ, Fingleton B, Gorden DL, Matrisian LM. 2006. Matrix metalloproteinase-9 from bone marrow-derived cells contributes to survival but not growth of tumor cells in the lung microenvironment. Cancer Res 66: 259-266.

Alcaraz J, Xu R, Mori H, Nelson CM, Mroue R, Spencer VA, Brownfield D, Radisky DC, Bustamante C, Bissell MJ. 2008. Laminin and biomimetic extracellular elasticity enhance functional differentiation in mammary epithelia. $E M B O J$ 27: $2829-2838$. 
Barcellos-Hoff MH, Aggeler J, Ram TG, Bissell MJ. 1989. Functional differentiation and alveolar morphogenesis of primary mammary cultures on reconstituted basement membrane. Development 105: 223-235.

Bergers G, Brekken R, McMahon G, Vu TH, Itoh T, Tamaki K, Tanzawa K, Thorpe P, Itohara S, Werb Z, et al. 2000. Matrix metalloproteinase-9 triggers the angiogenic switch during carcinogenesis. Nat Cell Biol 2: 737-744.

Bissell DM. 1981. Primary hepatocyte culture: Substratum requirements and production of matrix components. Fed Proc 40: 2469-2473.

Bissell MJ. 1981. The differentiated state of normal and malignant cells or how to define a 'normal' cell in culture. Int Rev Cytol 70: 27-100.

Bissell MJ, Kenny PA, Radisky DC. 2005. Microenvironmental regulators of tissue structure and function also regulate tumor induction and progression: The role of extracellular matrix and its degrading enzymes. Cold Spring Harb Symp Quant Biol 70: 343-356.

Bloomston M, Zervos EE, Rosemurgy AS 2nd. 2002. Matrix metalloproteinases and their role in pancreatic cancer: A review of preclinical studies and clinical trials. Ann Surg Oncol 9: 668-674.

Briand P, Nielsen KV, Madsen MW, Petersen OW. 1996. Trisomy $7 \mathrm{p}$ and malignant transformation of human breast epithelial cells following epidermal growth factor withdrawal. Cancer Res 56: 2039-2044.

Byun HJ, Hong IK, Kim E, Jin YJ, Jeoung DI, Hahn JH, Kim YM, Park SH, Lee H. 2006. A splice variant of CD99 increases motility and MMP-9 expression of human breast cancer cells through the AKT-, ERK-, and JNK-dependent AP-1 activation signaling pathways. J Biol Chem 281: 34833-34847.

Chen A, Cuevas I, Kenny PA, Miyake H, Mace K, Ghajar C, Boudreau A, Bissell M, Boudreau N. 2009. Endothelial cell migration and vascular endothelial growth factor expression are the result of loss of breast tissue polarity. Cancer Res 69: 6721-6729.

Coussens LM, Tinkle CL, Hanahan D, Werb Z. 2000. MMP-9 supplied by bone marrow-derived cells contributes to skin carcinogenesis. Cell 103: 481-490.

Coussens LM, Fingleton B, Matrisian LM. 2002. Matrix metalloproteinase inhibitors and cancer: Trials and tribulations. Science 295: 2387-2392.

Debnath J, Mills KR, Collins NL, Reginato MJ, Muthuswamy SK, Brugge JS. 2002. The role of apoptosis in creating and maintaining luminal space within normal and oncogeneexpressing mammary acini. Cell 111: 29-40.

Deryugina EI, Quigley JP. 2006. Matrix metalloproteinases and tumor metastasis. Cancer Metastasis Rev 25: 9-34.

Egeblad M, Werb Z. 2002. New functions for the matrix metalloproteinases in cancer progression. Nat Rev Cancer 2: 161-174.

Elston CW, Ellis IO. 2002. Pathological prognostic factors in breast cancer. I. The value of histological grade in breast cancer: Experience from a large study with long-term follow-up. Histopathology 41: 154-161.

Fournier MV, Martin KJ, Kenny PA, Xhaja K, Bosch I, Yaswen P, Bissell MJ. 2006. Gene expression signature in organized and growth-arrested mammary acini predicts good outcome in breast cancer. Cancer Res 66: 7095-7102.

Gudjonsson T, Ronnov-Jessen L, Villadsen R, Rank F, Bissell MJ, Petersen OW. 2002. Normal and tumor-derived myoepithelial cells differ in their ability to interact with luminal breast epithelial cells for polarity and basement membrane deposition. J Cell Sci 115: 39-50.

Halbleib JM, Saaf AM, Brown PO, Nelson WJ. 2007. Transcriptional modulation of genes encoding structural characteristics of differentiating enterocytes during development of a polarized epithelium in vitro. Mol Biol Cell 18: 4261-4278.

Herron GS, Banda MJ, Clark EJ, Gavrilovic J, Werb Z. 1986. Secretion of metalloproteinases by stimulated capillary endothelial cells. II. Expression of collagenase and stromelysin activities is regulated by endogenous inhibitors. I Biol Chem 261: 2814-2818.

Itoh T, Tanioka M, Matsuda H, Nishimoto H, Yoshioka T, Suzuki R, Uehira M. 1999. Experimental metastasis is suppressed in MMP-9-deficient mice. Clin Exp Metastasis 17: 177-181.

Itoh M, Nelson CM, Myers CA, Bissell MJ. 2007. Rap1 integrates tissue polarity, lumen formation, and tumorigenic potential in human breast epithelial cells. Cancer Res 67: 4759-4766.

Jenny RJ, Mann KG, Lundblad RL. 2003. A critical review of the methods for cleavage of fusion proteins with thrombin and factor Xa. Protein Expr Purif 31: 1-11.

Kenny PA, Bissell MJ. 2007. Targeting TACE-dependent EGFR ligand shedding in breast cancer. J Clin Invest 117: 337-345.

Lee GY, Kenny PA, Lee EH, Bissell MJ. 2007. Three-dimensional culture models of normal and malignant breast epithelial cells. Nat Methods 4: 359-365.

Li HC, Cao DC, Liu Y, Hou YF, Wu J, Lu JS, Di GH, Liu G, Li FM, Ou ZL, et al. 2004. Prognostic value of matrix metalloproteinases (MMP-2 and MMP-9) in patients with lymph node-negative breast carcinoma. Breast Cancer Res Treat 88: 75-85.

Liu JF, Crepin M, Liu JM, Barritault D, Ledoux D. 2002. FGF-2 and TPA induce matrix metalloproteinase-9 secretion in MCF-7 cells through PKC activation of the Ras/ERK pathway. Biochem Biophys Res Commun 293: 1174-1182.

Liu H, Radisky DC, Wang F, Bissell MJ. 2004. Polarity and proliferation are controlled by distinct signaling pathways downstream of PI3-kinase in breast epithelial tumor cells. J Cell Biol 164: 603-612.

Martin MD, Carter KJ, Jean-Philippe SR, Chang M, Mobashery S, Thiolloy S, Lynch CC, Matrisian LM, Fingleton B. 2008. Effect of ablation or inhibition of stromal matrix metalloproteinase-9 on lung metastasis in a breast cancer model is dependent on genetic background. Cancer Res 68: 62516259.

Meloche S, Pouyssegur J. 2007. The ERK1/2 mitogen-activated protein kinase pathway as a master regulator of the G1- to S-phase transition. Oncogene 26: 3227-3239.

Muschler J, Lochter A, Roskelley CD, Yurchenco P, Bissell MJ. 1999. Division of labor among the $\alpha 6 \beta 4$ integrin, $\beta 1$ integrins, and an E3 laminin receptor to signal morphogenesis and $\beta$-casein expression in mammary epithelial cells. Mol Biol Cell 10: 2817-2828.

Muthuswamy SK, Li D, Lelievre S, Bissell MJ, Brugge JS. 2001. ErbB2, but not ErbB1, reinitiates proliferation and induces luminal repopulation in epithelial acini. Nat Cell Biol 3: 785-792.

Myers CA, Schmidhauser C, Mellentin-Michelotti J, Fragoso G, Roskelley CD, Casperson G, Mossi R, Pujuguet P, Hager G, Bissell MJ. 1998. Characterization of BCE-1, a transcriptional enhancer regulated by prolactin and extracellular matrix and modulated by the state of histone acetylation. Mol Cell Biol 18: $2184-2195$.

Overall CM, Kleifeld O. 2006. Tumour microenvironmentOpinion: Validating matrix metalloproteinases as drug targets and anti-targets for cancer therapy. Nat Rev Cancer 6: 227-239.

Page-McCaw A, Ewald AJ, Werb Z. 2007. Matrix metalloproteinases and the regulation of tissue remodelling. Nat Rev Mol Cell Biol 8: 221-233. 
Pearson GW, Hunter T. 2009. PI-3 kinase activity is necessary for ERK1/2-induced disruption of mammary epithelial architecture. Breast Cancer Res 11: R29. doi: 10.1186/bcr2259.

Petersen OW, Ronnov-Jessen L, Howlett AR, Bissell MJ. 1992. Interaction with basement membrane serves to rapidly distinguish growth and differentiation pattern of normal and malignant human breast epithelial cells. Proc Natl Acad Sci 89: 9064-9068.

Price DJ, Avraham S, Feuerstein J, Fu Y, Avraham HK. 2002. The invasive phenotype in HMT-3522 cells requires increased EGF receptor signaling through both PI 3-kinase and ERK 1,2 pathways. Cell Commun Adhes 9: 87-102.

Pugacheva EN, Roegiers F, Golemis EA. 2006. Interdependence of cell attachment and cell cycle signaling. Curr Opin Cell Biol 18: 507-515.

Radisky DC, Levy DD, Littlepage LE, Liu H, Nelson CM, Fata JE, Leake D, Godden EL, Albertson DG, Nieto MA, et al. 2005. Raclb and reactive oxygen species mediate MMP3-induced EMT and genomic instability. Nature 436: 123-127.

Rizki A, Weaver VM, Lee SY, Rozenberg GI, Chin K, Myers CA, Bascom JL, Mott JD, Semeiks JR, Grate LR, et al. 2008. A human breast cell model of preinvasive to invasive transition. Cancer Res 68: 1378-1387.

Roy R, Louis G, Loughlin KR, Wiederschain D, Kilroy SM, Lamb CC, Zurakowski D, Moses MA. 2008. Tumor-specific urinary matrix metalloproteinase fingerprinting: Identification of high molecular weight urinary matrix metalloproteinase species. Clin Cancer Res 14: 6610-6617.

Samuels ML, Weber MJ, Bishop JM, McMahon M. 1993. Conditional transformation of cells and rapid activation of the mitogen-activated protein kinase cascade by an estradioldependent human raf-1 protein kinase. Mol Cell Biol 13: 6241-6252.

Sanceau J, Truchet S, Bauvois B. 2003. Matrix metalloproteinase9 silencing by RNA interference triggers the migratoryadhesive switch in Ewing's sarcoma cells. J Biol Chem 278: 36537-36546.

Schmidhauser C, Casperson GF, Myers CA, Sanzo KT, Bolten S, Bissell MJ. 1992. A novel transcriptional enhancer is involved in the prolactin- and extracellular matrix-dependent regulation of $\beta$-casein gene expression. Mol Biol Cell 3: 699-709.

Spancake KM, Anderson CB, Weaver VM, Matsunami N, Bissell MJ, White RL. 1999. E7-transduced human breast epithelial cells show partial differentiation in three-dimensional culture. Cancer Res 59: 6042-6045.

Streuli CH, Bissell MJ. 1990. Expression of extracellular matrix components is regulated by substratum. I Cell Biol 110: 1405-1415.

Streuli CH, Bailey N, Bissell MJ. 1991. Control of mammary epithelial differentiation: Basement membrane induces tissue-specific gene expression in the absence of cell-cell interaction and morphological polarity. $J$ Cell Biol 115: 1383-1395.

Tsai MS, Shamon-Taylor LA, Mehmi I, Tang CK, Lupu R. 2003. Blockage of heregulin expression inhibits tumorigenicity and metastasis of breast cancer. Oncogene 22: 761-768.

Vizoso FJ, Gonzalez LO, Corte MD, Rodriguez JC, Vazquez J, Lamelas ML, Junquera S, Merino AM, Garcia-Muniz JL. 2007. Study of matrix metalloproteinases and their inhibitors in breast cancer. Br J Cancer 96: 903-911.

Walpita D, Hay E. 2002. Studying actin-dependent processes in tissue culture. Nat Rev Mol Cell Biol 3: 137-141.

Wang F, Weaver VM, Petersen OW, Larabell CA, Dedhar S, Briand P, Lupu R, Bissell MJ. 1998. Reciprocal interactions between $\beta 1$-integrin and epidermal growth factor receptor in three-dimensional basement membrane breast cultures: A different perspective in epithelial biology. Proc Natl Acad Sci 95: 14821-14826.

Wang F, Hansen RK, Radisky D, Yoneda T, Barcellos-Hoff MH, Petersen OW, Turley EA, Bissell MJ. 2002. Phenotypic reversion or death of cancer cells by altering signaling pathways in three-dimensional contexts. J Natl Cancer Inst 94: 1494-1503.

Weaver VM, Petersen OW, Wang F, Larabell CA, Briand P, Damsky C, Bissell MJ. 1997. Reversion of the malignant phenotype of human breast cells in three-dimensional culture and in vivo by integrin blocking antibodies. I Cell Biol 137: 231-245.

Weaver VM, Lelievre S, Lakins JN, Chrenek MA, Jones JC, Giancotti F, Werb Z, Bissell MJ. 2002. $\beta 4$ integrin-dependent formation of polarized three-dimensional architecture confers resistance to apoptosis in normal and malignant mammary epithelium. Cancer Cell 2: 205-216.

White SA, Allshire RC. 2004. Loss of Dicer fowls up centromeres. Nat Cell Biol 6: 696-697.

Wodarz A, Nathke I. 2007. Cell polarity in development and cancer. Nat Cell Biol 9: 1016-1024.

Wu ZS, Wu Q, Yang JH, Wang HQ, Ding XD, Yang F, Xu XC. 2008. Prognostic significance of MMP-9 and TIMP-1 serum and tissue expression in breast cancer. Int I Cancer 122: 2050-2056.

$\mathrm{Xu}$ R, Nelson CM, Muschler JL, Veiseh M, Vonderhaar BK, Bissell MJ. 2009. Sustained activation of STAT5 is essential for chromatin remodeling and maintenance of mammaryspecific function. I Cell Biol 184: 57-66.

Zhang S, Li Z, Wu X, Huang Q, Shen HM, Ong CN. 2006. Methyl-3-indolylacetate inhibits cancer cell invasion by targeting the MEK1/2-ERK1/2 signaling pathway. Mol Cancer Ther 5: 3285-3293.

Zucker S, Cao J, Chen WT. 2000. Critical appraisal of the use of matrix metalloproteinase inhibitors in cancer treatment. Oncogene 19: 6642-6650. 


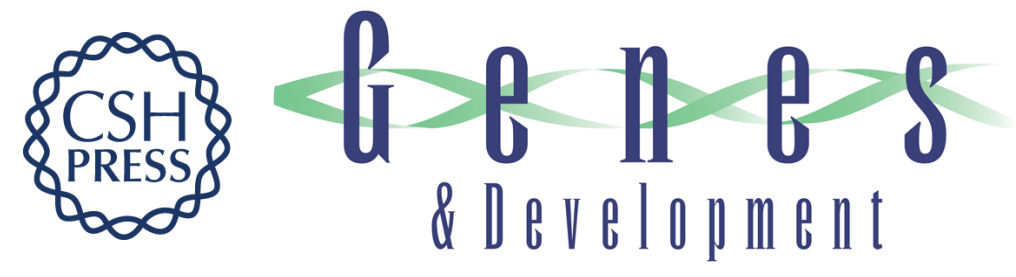

\section{Raf-induced MMP9 disrupts tissue architecture of human breast cells in three-dimensional culture and is necessary for tumor growth in vivo}

Alain Beliveau, Joni D. Mott, Alvin Lo, et al.

Genes Dev. 2010, 24:

Access the most recent version at doi:10.1101/gad.1990410

Supplemental http://genesdev.cshlp.org/content/suppl/2010/12/13/24.24.2800.DC1
Material

References This article cites 62 articles, 29 of which can be accessed free at:

http://genesdev.cshlp.org/content/24/24/2800.full.html\#ref-list-1

License

Email Alerting Receive free email alerts when new articles cite this article - sign up in the box at the top

Service right corner of the article or click here.

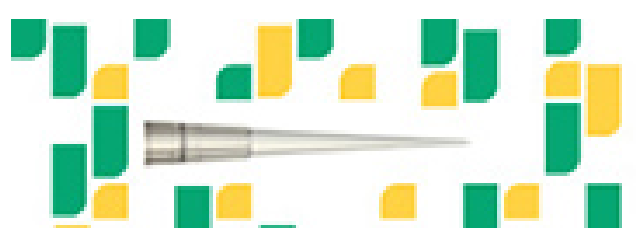

Focused on your science. 